\title{
Dr. Marcos Pedro Canassa - *29/06/1950 - † 29/06/2005
}

Faleceu no dia 7 de julho próximo passado, após mais de três anos de convívio com a doença, o colega admirado por todos, Marcos Pedro Canassa.

Filho de Pedro Canassa e Elena Arduini Canassa, nasceu em Conquista, MG. Aos quatro anos de idade sua família mudou para Uberaba, onde cursou o primeiro e segundo graus.

Formado em 1977 pela Faculdade de Medicina do Triângulo Mineiro (FMTM), atualmente Universidade Federal do Triângulo Mineiro (UFTM). Foi integrante da primeira turma de Médicos em Especialização em Anestesiologia do Hospital Universitário da UFRJ (1978-1979). Com muita alegria e satisfação sempre se lembrava dos integrantes do CET que o preparou: Doutores Bento Gonçalves, Calasans, Carmen, Drumond, Peter Spiegel, assim como os da geração seguinte, Luiz Bomfim e Fabiano. Em 1980, obteve o primeiro lugar em concurso público federal para integrar o recém-criado Serviço de Anestesiologia do Hospital Escola (HE) da FMTM. Foi o grande incentivador para a implantação da Residência em Anestesiologia no HE da FMTM (MEC), iniciada em 1980, e posteriormente da especialização (SBA). Nos anos de 1980 e 1981 prestou com brilhantismo o exame para obtenção do TEA, hoje TSA.

No ano de 1981, cursamos o primeiro curso de Reanimação Cardiopulmonar e Cerebral (RCPC), organizado pelos Doutores Masami Katayama e John Cook Lane, realizado no Hospital da Bosch, em Campinas. Em duas outras oportunidades (1982 e 1985) voltamos a freqüentar este mesmo curso, já com a estação Mega.

Em 8 de janeiro de 1983, casou-se com Ivonete de Faria Canassa, tendo dois filhos: Paulo Guilherme, que tornou realidade um dos sonhos do pai ao ingressar em 2003 na FMTM, e Ana Luisa. Portador de uma voz clara e impostada, com freqüência era o mestre de cerimônia em reuniões sociais, tendo sido apresentador de programas musicais em rádio.

Homem de princípios morais rígidos, na sua fase final de vida negou-se de forma incisiva a acatar a orientação de usar a cannabis sativa na terapia paliativa da dor.

Com o falecimento do amigo Canassa perdemos não apenas o convívio de um profissional exemplar, mas também perdemos exemplos de cidadania e de um homem livre e de bons costumes.

Nilson de Camargos Roso, TSA

Co-Responsável pelo CET do HE da FMTM
After more than 3 years living with the disease, our dearest colleague Marcos Pedro Canassa has passed away on July 7, 2005.

Son of Pedro Canassa and Elena Arduini Canassa, he was born in Conquista, MG. His family moved to Uberaba when he was four years old and there he finished elementary school.

Dr. Canassa graduated in 1977 from the School of Medicine Triângulo Mineiro (FMTM), currently Federal University Triângulo Mineiro (UFTM). He was part of the first group of Physicians in Specialization in Anesthesiology of the Teaching Hospital, UFRJ (19781979). With satisfaction and happily he used to remember CET members who prepared him: Drs. Bento Gonçalves, Calasans, Carmen, Drumond, Peter Spiegel, as well as those from the next generation, Luiz Bomfim and Fabiano. In 1980 he was the first in a federal public contest to integrate the recently created Anesthesiology Service of FMTM's Teaching Hospital (TH). He was a major stimulator of the implementation of Residence in Anesthesiology in FMTM,s TH (MEC), started in 1980, and afterward of the specialization (SBA). In 1980 and 1981, he brilliantly completed the tests to obtain TEA, today TSA.

In 1981 we have together attended the $1^{\text {st }}$ Cardiopulmonary and Cerebral Resuscitation course (RCPC) organized by Drs. Masami Katayama and John Cook Lane in the Bosch Hospital, Campinas. We returned to this same course in 1982 and 1985, already with the Mega station.

On January 8, 1983 he married Ivonete de Faria Canassa and had two children: Paulo Guilherme, who made one of his father's dream come true when entering FMTM in 2003, and Ana Luisa. With clear and pitched voice, he was often master of ceremonies in social meetings, having presented radio music programs.

With sound moral principles, at the end of his life he incisively refused to accept the orientation of using cannabis sativa for pain relief.

With the passing away of our friend Canassa we have lost not only an exemplary professional, but also examples of citizenship and of a free and morally untouched man.

Nilson de Camargos Roso, TSA, M.D. Co-Responsable for CET of FMTM's HE 